\title{
MULTIMEDIA INTERAKTIF DALAM PEMBELAJARAN KONSEP LISTRIK BAGI CALON GURU
}

\author{
Gunawan, Ahmad Harjono, Sutrio \\ Program Studi Pendidikan Fisika \\ Universitas Mataram \\ Mataram, Indonesia \\ Email : gunawan@unram.ac.id
}

\begin{abstract}
There are many abstract concepts in physics. This raises its own difficulties in learning physics. The difficulty in teaching abstract concepts can be solved using computer technology. Computer technology presents opportunities for learning abstract concepts, such as through the use of interactive multimedia in learning physics. In this study has developed an interactive multimedia on the concept of electricity. This study aims to examine the impact of the use of interactive multimedia on student mastery of the concept of electricity. The results showed an increase in mastery of concepts in both classes. The highest increase occurred in the concept of Coulomb's law, which is 68.6\% (experimental group) and 48\% (control group). Mastery electric concept experimental group is greater than the control group, indicates that interactive multimedia effective in supporting the process of learning physics.
\end{abstract}

Keywords: Interactive Multimedia, Electricity Concepts

\section{Pendahuluan}

Fisika merupakan bagian dari sains yang memfokuskan kajiannya pada materi, energi, dan hubungan antara keduanya. Beberapa konsep dalam fisika termasuk konsep abstrak. Karakteristik beberapa konsep yang abstrak dalam fisika, menyebabkan adanya kesulitan tersendiri dalam visualisasi dan penyampaiannya kepada peserta didik. Konsep abstrak merupakan konsep yang sulit divisualisasikan atau ditampilkan prosesnya secara langsung melalui kegiatan laboratorium riil sekalipun. Hal ini kemudian berimplikasi pada rendahnya penguasaan konsep dan perolehan hasil belajar peserta didik.

Perkembangan teknologi komputer menghadirkan peluang untuk inovasi-inovasi dalam pembelajaran sains, khususnya fisika. Teknologi komputer adalah sebuah penemuan yang memungkinkan menghadirkan sebagian atau semua bentuk interaksi sehingga pembelajaran akan lebih optimal. Konsep-konsep fisika tersebut direalisasikan dalam program komputer menggunakan piranti lunak yang mudah dipelajari.

Perkembangan teknologi informasi menyediakan kesempatan untuk membangun dan menggunakan animasi komputer untuk pembelajaran yang berorientasi pada representasi mikroskopik. Hal ini dapat diwujudkan dengan bantuan animasi komputer karena animasi komputer dapat memvisualisasikan proses-proses abstrak yang mustahil dilihat atau dibayangkan.

Perkembangan di bidang ICT memberikan pengaruh yang signifikan terhadap bagaimana proses pembelajaran fisika, khususnya pada efektivitas pembelajaran, efisiensi waktu dan fasilitas pendukung pembelajaran lainnya. Teknologi komputer dapat diadaptasi menjadi sebuah pendekatan pembelajaran yang aktif. Teknologi komputer memungkinkan adanya perpaduan antara tatap-muka (face to face) dengan pembelajaran online. Beberapa hal yang perlu dipertimbangkan antara lain pendekatan yang mungkin diterapkan, strategi, teknik, dan peralatan yang ada [1].

Teknologi komputer yang digunakan dapat menggunakan format online maupun offline. Teknologi komputer dapat digunakan mendukung pembelajaran berbasis ICT, eksperimen virtual, asesmen berbasis ICT, maupun penggunaannya sebagai media pembelajaran [2]. Penggunaan media pembelajaran berbasis ICT dapat melalui pemanfaatan 
internet maupun penggunaan komputer sebagai multimedia interaktif.

Penggunaan multimedia interaktif di perguruan tinggi diharapkan dapat merangsang pikiran, perasaan, minat, serta perhatian mahasiswa sedemikan rupa sehingga proses pembelajaran dapat lebih optimal. Hal ini penting karena terdapat berbagai cara mahasiswa dalam memproses informasi yang bersifat unik. Ada yang lebih mudah memproses informasi visual, sebagian lain lebih mudah kalau ada suara, dan sebagian lain akan memahami dengan mudah atau lebih baik jika melakukannya dengan praktek.

Beberapa penelitian terdahulu juga menunjukkan sejumlah kelebihan multimedia dalam pembelajaran fisika. McKagan [3], menemukan bahwa penggunaan multimedia efektif dalam pembelajaran konsep mekanika kuantum terbukti membantu mahasiswa membangun model mental dan intuisi tentang mekanika kuantum meliputi representasi visual dari konsep abstrak dan proses mikroskopik yang tidak dapat diobservasi secara langsung. Penelitian ini juga menunjukkan bahwa simulasi yang digunakan efektif dalam membantu mahasiswa belajar dan telah mengungkapkan pengertian baru yang mendalam baru pada cara pikir mereka tentang mekanika kuantum.

Sadaghiani [4], dalam penelitiannya menemukan bahwa meskipun waktu belajar di kelas berkurang, hasil belajar mahasiswa pada konsep listrik dan magnet tidak menurun. Pada kenyataannya, penggunaan multimedia dalam pembelajaran hybridonline tersebut menghasilkan pengaruh positif pada kinerja mahasiswa, khususnya pada tes konseptual dan diskusi pertanyaan di kelas.

\section{TinjauAn Pustaka}

Salah satu teknologi komputer yang umum digunakan dalam pembelajaran adalah multimedia interaktif. Ivers \& Baron [5], mendefinisikan multimedia sebagai penggunaan beberapa media untuk menyajikan informasi. Kombinasi ini dapat berisi teks, grafik, animasi, gambar, video, dan suara.

Multimedia terbagi menjadi dua kategori, yaitu: multimedia linier dan multimedia interaktif. Multimedia linier adalah suatu multimedia yang tidak dilengkapi dengan alat pengontrol apapun yang dapat dioperasikan oleh penguna, contohnya TV dan film. Multimedia interaktif adalah suatu multimedia yang dilengkapi dengan alat pengontrol yang dapat dioperasikan oleh pengguna, sehingga pengguna dapat memilih apa yang dikehendaki untuk proses selanjutnya. Contoh multimedia interaktif adalah: multimedia pembelajaran interaktif, aplikasi game, dan lain-lain [2].

Munir [6], menyarankan penggunaan multimedia agar proses pembelajaran menjadi lebih berkesan dan bermakna. Multimedia merupakan sistem yang mendukung komunikasi guru dengan siswa selama proses pembelajaran melalui teks, audio, gambar, animasi, video, dan grafis.

Finkelstein [7], mengatakan bahwa komputer dapat digunakan untuk menunjang pelaksanaan praktikum fisika baik untuk mengumpulkan data, menyajikan, dan mengolah data. Selain itu, komputer juga dapat digunakan untuk memodifikasi eksperimen dan menampilkan eksperimen lengkap dalam bentuk virtual.

Penggunaan komputer dalam proses belajar mengajar memberikan beberapa dampak positif, diantaranya: kontribusi pada sebuah evolusi cara siswa belajar, memperkaya dan memperluas pengalaman belajar siswa, menyediakan alat yang kuat bagi siswa untuk eksplorasi web, memberikan kontribusi pada evolusi teori-teori belajar, dan lain sebagainya [8].

Pada abad XXI, terdapat beberapa keterampilan yang menjadi fokus perhatian, yaitu pemecahan masalah, keterampilan berpikir kritis, serta literasi ICT. Beberapa keterampilan belajar menggunakan ICT, diantaranya: (1) keterampilan dalam media dan informasi, mulai dari menganalisis, mengakses, mengatur, mengintegrasikan, mengevaluasi dan membuat informasi dalam berbagai bentuk dan media. Juga keterampilan dalam aturan penggunaan media dalam masyarakat, (2) keterampilan komunikasi, meliputi komunikasi lisan, komunikasi tulis, dan komunikasi melalui multimedia dalam berbagai bentuk dan konteksnya, (3) keterampilan 
interpersonal dan self-direction. Menjadi lebih produktif dalam menyelesaikan tugas dan mengembangkan minat dalam meningkatkan keterampilan secara mandiri.

Alasan penggunaan komputer dalam pembelajaran, antara lain: (1) kemampuan komputer untuk menyajikan informasi dalam bentuk multimedia (teks, gambar, audio, video, animasi, simulasi) dan aspek interaktif, (2) komputer dapat diprogram untuk melakukan perhitungan, memeriksa hasil tes dan memberikan umpan balik, (3) teknologi internet memungkinkan bahan ajar dapat diakses kapan saja, dimana saja dan oleh siapa saja yang terhubung ke internet [9].

Proyek multimedia mendorong siswa untuk bekerja dalam kelompok, mengungkapkan pengetahuan mereka dalam berbagai cara, memecahkan masalah, merevisi karya mereka sendiri, dan membangun pengetahuan. Siswa memiliki kesempatan untuk belajar dan menerapkan keterampilan dunia nyata. Mereka belajar nilai kerja sama tim; dampak dan pentingnya media yang berbeda, termasuk masalah desain, media kesesuaian dan validitas, dan hukum hak cipta; tantangan berkomunikasi dengan peserta yang berbeda; pentingnya penelitian, perencanaan, dan keterampilan organisasi; pentingnya presentasi dan keterampilan berbicara; dan bagaimana menerima dan memberikan umpan balik yang konstruktif. Membuat proyek multimedia membantu untuk memperkuat keterampilan teknologi siswa dan mempersiapkan mereka untuk tuntutan karir masa depan [2].

Multimedia terdiri dari berbagai jenis media untuk menyampaikan pesan/informasi kepada pengguna sesuai tujuan dan fungsinya. Terdapat beberapa komponen utama multimedia yang dirangkai dalam format digital yang disusun sedemikian rupa sehingga menarik dan memotivasi pengguna untuk belajar. Komponen-komponen tersebut adalah teks, gambar, audio, video, dan animasi. Satu komponen lagi bisa ditambahkan yaitu interaktif, sehingga multimedia bisa disebut sebagai 'multimedia interaktif' [2].
Berdasarkan hasil penelitian Gunawan et al [10], dapat disimpulkan bahwa penguasaan konsep mahasiswa yang belajar menggunakan multimedia interaktif lebih tinggi dibandingkan dengan mahasiswa yang diajarkan secara konvensional. Pembelajaran menggunakan multimedia interaktif membantu mahasiswa untuk mengingat kembali konsep dasar yang pernah diterima sebelumnya lebih baik dibandingkan pembelajaran secara konvensional. Hal ini ditunjukkan adanya perbedaan yang signifikan pada konsep-konsep dasar setiap materi antara yang belajar dengan multimedia interaktif dengan mahasiswa yang belajar secara konvensional.

Simulasi komputer dapat digunakan sebagai alternatif media pembelajaran karena dapat membantu siswa mengatasi kelemahannya dalam teori dan pengembangan pemahaman konsep fisika. Zacharia [11], menyatakan bahwa penggunaan simulasi interaktif membantu mahasiswa memvisualisasikan masalah dan pemecahannya, juga dapat menumbuhkan sikap positif terhadap fisika. Penggunaan multimedia interaktif dapat lebih meningkatkan kemampuan inferensi logika dan kemampuan menarik kesimpulan mahasiswa [12], begitupun halnya dengan penggunaan laboratorium virtual. Penggunaan laboratorium virtual dapat membuat mahasiswa berpikiran lebih terbuka dan memotivasi mereka terus mencoba menemukan secara mandiri konsep fisika yang diharapkan [13] Laboratorium virtual juga terbukti membantu mahasiswa belajar dalam penalaran logis sehingga kemampuan inferensi logika dan kemampuan menarik kesimpulan mahasiswa mengalami peningkatan [14].

Konsep merupakan gambaran mental dari gejala alam yang mempunyai lingkup yang luas mengenai keteraturan kejadian atau obyek, yang dinyatakan dalam suatu label konsep. Konsep adalah dasar bagi perkembangan mental yang lebih tinggi untuk merumuskan prinsip-prinsip dan generalisasigeneralisasi. Namun secara umum konsep adalah suatu abstraksi yang menggambarkan ciri-ciri umum sekelompok objek, peristiwa, atau fenomena lainnya [15]. 
Konsep dalam fisika biasanya dinyatakan dalam bahasa simbolik. Simbol yang digunakan merupakan manipulasi dari satu atau lebih penalaran proses IPA yang tidak dapat dinyatakan dalam bahasa sehari-hari. Simbol merupakan nama dari sebuah konsep yang berkaitan dengan simbol lainnya, sehingga memungkinkan adanya jalan pemikiran yang teratur. Dalam fisika, peserta didik dituntut untuk memahami konsep-konsep yang ada. Pemahaman konsep akan membantu peserta didik memahami dan menyelesaikan soal-soal, ataupun menyelesaikan permasalahan yang dihadapinya dalam kehidupan. Penguasaan konsep adalah cara memahami sesuatu yang sudah terpola dalam pikirannya yang diakses oleh simbol verbal atau tertulis.

\section{METODE PENELITIAN}

Penelitian ini termasuk penelitian pengembangan. Dalam penelitian ini telah dikembangkan suatu model multimedia interaktif (MMI) untuk pembelajaran fisika pada konsep listrik. MMI dikembangkan menggunakan program Macromedia Flash 8. Instrumen yang digunakan untuk pengumpulan data penguasaan konsep listrik berupa tes pilihan ganda. Subjek dalam penelitian ini adalah mahasiswa program studi pendidikan fisika yang sedang mengikuti perkuliahan fisika dasar pada salah satu LPTK di Mataram.

Data hasil penguasaan konsep setiap materi yang diperoleh selanjutnya dianalisis untuk mengetahui tingkat keberhasilan penggunaan multimedia dalam pembelajaran yang selanjutnya dibandingkan dengan kelas yang belajar materi yang sama dengan cara konvensional. Dalam rangka antisipasi kesalahan penafsiran perolehan skor gain setiap mahasiswa, juga dihitung besarnya $\mathrm{N}$-gain dengan menggunakan rumus [16]:

$$
\mathrm{N}-\text { gain }=\frac{\mathrm{S}_{\text {post }}-\mathrm{S}_{\text {pre }}}{\mathrm{S}_{\max }-\mathrm{S}_{\text {pre }}} \times 100 \%
$$

\section{HASIL DAN PEMBAHASAN}

Materi listrik dalam penelitian ini dibatasi pada konsep listrik statis yang secara garis besar dapat dikelompokkan menjadi 5 label konsep, yaitu hukum
Coulomb, medan listrik, hukum Gauss, potensial listrik, dan energi listrik. Setiap label konsep dianalisis ketercapaiannya berdasarkan perolehan skor tes awal, tes akhir, dan gain ternormalisasi. Persentase peningkatan penguasaan konsep mahasiswa pada setiap label konsep kelas eksperimen dan kelas kontrol disajikan pada gambar 1 .

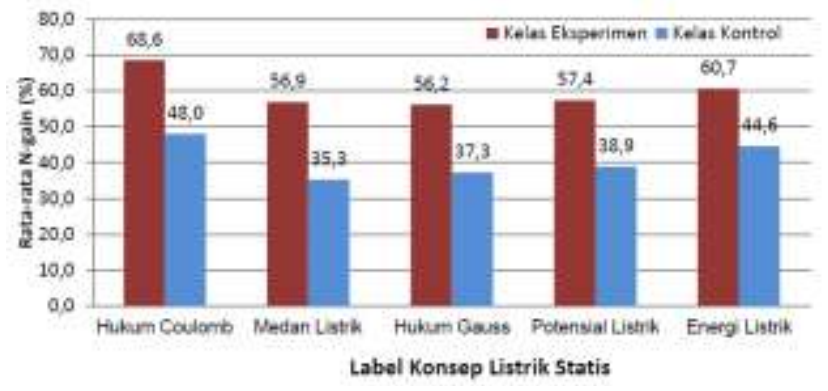

Gambar 1. Perbandingan Rata-rata Skor N-gain Setiap Label Konsep Listrik pada Kedua Kelas

Berdasarkan analisis pada setiap label konsep dapat diketahui bahwa peningkatan tertinggi pada kelas eksperimen sebesar $68,6 \%$ pada materi hukum Coulomb, sedangkan terendah pada materi hukum Gauss sebesar 56,2\%. Pada kelas kontrol peningkatan tertinggi terjadi pada materi hukum Coulomb 48,0\%, terendah pada materi medan listrik sebesar 35,3\%. Peningkatan tertinggi pada label konsep hukum Coulomb dapat dimengerti, selain karena merupakan materi awal dalam penyampaiannya juga disebabkan materi ini merupakan materi yang pernah diterima sebelumnya di sekolah menengah. Hal menarik kemudian, pada materi ini terjadi perbedaan tertinggi pada peningkatan kedua kelas. Hal ini dapat disebabkan multimedia interaktif yang dikembangkan dapat membantu mahasiswa memahami konsep dengan lebih baik. Ilustrasi dan visualisasi yang diberikan memotivasi mahasiswa untuk tetap belajar. Mahasiswa dilibatkan dalam rangkaian percobaan yang memandunya untuk dapat menemukan sendiri konsep fisika pada materi listrik tersebut.

Materi listrik merupakan salah satu materi penting dan kompleks dalam fisika. Mahasiswa pada berbagai tingkat pendidikan mengalami miskonsepsi dan kesulitan dalam memahami konsep dasar listrik. Sebagai solusinya dikembangkan beberapa pendekatan yang kemudian diuji secara empirik, salah 
satunya melalui penerapan simulasi interaktif. Hasil penelitian Nurmi \& Jaakola [17], menunjukkan bahwa kelompok Simulation Learning Object (SLO) dengan tugas terstruktur adalah kelompok yang mengalami peningkatan tertinggi (yang paling diuntungkan). Faktor pengaturan aktif menunjukkan pengaruh yang signifikan pada sikap belajar mahasiswa, tetapi perbandingan antara bentuk penugasan terstruktur dan yang tidak terstruktur tidak menunjukkan perbedaan yang signifikan.

Perkins. K, et al. [18], menyatakan bahwa kesulitan untuk memahami konsep dasar listrik dapat diatasi melalui penggunaan simulasi interaktif dengan tugas terstruktur dan tidak terstruktur. Hasil penelitian menunjukkan penggunaan simulasi komputer efektif meningkatkan penguasaan konsep listrik mahasiswa.

Hasil penelitian Finkelstein, et. al [19], menunjukkan bahwa penguasaan konsep listrik dan keterampilan mahasiswa yang belajar dan eksperimen menggunakan simulasi komputer lebih tinggi dibandingkan 2 kelompok lainnya yaitu kelompok dengan percobaan riil laboratorium dan kelompok konvensional tanpa percobaan laboratorium. Mahasiswa yang belajar menggunakan multimedia interaktif lebih mampu menggunakan prinsip-prinsip yang ada dalam konsep fisika. Rancangan multimedia interaktif yang dikembangkan melibatkan mahasiswa untuk memperoleh pengalaman, dan melakukan eksperimen-eksperimen yang mengizinkan mereka untuk menemukan prinsip-prinsip itu sendiri.

Finkelstein [20], menyatakan bahwa perkembangan teknologi komputer dapat digunakan untuk membantu meningkatkan pemahaman fisika mahasiswa baik sebagai multimedia interaktif maupun sumber online seperti halnya e-learning. Penggunaan sumber online terbukti membantu mahasiswa untuk belajar secara mandiri dan menemukan sendiri konsep-konsep penting yang ditargetkan.

\section{PENUTUP}

Dalam penelitian ini telah dikembangkan multimedia interaktif fisika untuk meningkatkan penguasaan konsep listrik mahasiswa. Hasil penelitian menunjukkan penguasaan konsep listrik mahasiswa yang diajarkan dengan pembelajaran berbasis multimedia interaktif lebih tinggi dibandingkan dengan mahasiswa yang diajarkan secara konvensional. Konsep yang mengalami peningkatan tertinggi adalah hukum Coulomb sebesar 68,6\% (kelompok eksperimen) dan 48\% (kelompok kontrol). Rata-rata tingkat penguasaan konsep listrik mahasiswa pada kelompok eksperimen lebih tinggi dibandingkan kelompok kontrol. Hal ini mengindikasikan bahwa penggunaan multimedia interaktif efektif mendukung proses pembelajaran fisika bagi calon guru.

\section{UCAPAN TERIMA KASIH}

Penulis menyampaikan ucapan terima kasih yang sebesar-besarnya kepada DP2M Dikti Kemendikbud yang telah memfasilitasi pembiayaan penelitian ini melalui Skim Penelitian Strategis Nasional Tahun 2012-2013. Ucapan terima kasih juga kami sampaikan kepada pihak lain yang telah memberikan masukan dan tinjauan kritis guna penyempurnaan tulisan ini.

\section{REFERENSI}

[1] Garrison, D.R \& Vaughan, N.D., (2008).Blended Learning in Higher Education. San Fransisco: John Willey \& Sons, Inc.

[2] Gunawan (2015). Model Pembelajaran Berbasis ICT. Mataram: FKIP Unram Press.

[3] McKagan et al. (2008). "Developing and Researching PhET simulations for Teaching Quantum Mechanics". American Journal of Physics, (76) pp. 406 - 417.

[4] Sadaghiani, Homeyra R. "Using multimedia learning modules in a hybrid-online course in electricity and magnetism". Physical Review Special Topics-Physics Education Research 7.1 (2011): 010102.

[5] Ivers, Karen \& Barron, Ann. (2002). Multimedia Projects In Education: Designing, Producing, and Assessing. Westport, CT : A Division of Greenwood Publishing Group, Inc.

[6] Munir (2001). Aplikasi Multimedia dalam Proses Belajar Mengajar. Mimbar Pendidikan XX (3). Universitas Pendidikan Indonesia. 
[7] Finkelstein, et.al. (2005). "When Learning About the Real World Is Better Done Virtually: A Study of Subtituting Computer Simulations for Laboratory Equipment". Physics Education Research. APS (1) $1-8$.

[8] Holmes, B \& Gardner, J. (2006). E-Learning: Concepts and Practice. London: Sage Publications Ltd.

[9] Setiawan, A. (2012). Pemanfaatan ICT untuk Pembelajaran Sains. Makalah disampaikan pada acara Workshop Pengembangan Media berbasis ICT, Mataram, 27 - 28 Januari 2012.

[10] Gunawan, et al. (2014). Penggunaan Multimedia Interaktif dalam Pembelajaran Fisika dan Implikasinya Pada Penguasaan Konsep Mahasiswa. Jurnal Pijar MIPA, Vol IX Nomor 1: $15-19$

[11] Zacharia, Z. \& Anderson, O.R. (2003). The Effects of an Interactive Computer-Based Simulation Prior to Performing A Laboratory Inquiry-Based Experiment on Students' Conceptual Understanding of Physics. American Journal of Physics, 71(6), 618-629.

[12] Gunawan. (2009). Pembelajaran Berbasis Multimedia Interaktif Untuk Meningkatkan Keterampilan Generik Sains Calon Guru Fisika. Jurnal Pijar MIPA. Vol. 4 No. 3

[13] Gunawan \& Liliasari (2012). Model Virtual Laboratory Fisika Modern untuk Meningkatkan Disposisi Berpikir Kritis Calon Guru. Jurnal Ilmiah Cakrawala Pendidikan. Th. XXXI, No. 2 : 185-199.

[14] Gunawan., Setiawan. A, \& Widyantoro D.H (2013). Model Virtual Laboratory Fisika Modern untuk Meningkatkan Keterampilan Generik Sains Calon Guru. Jurnal Pendidikan dan Pembelajaran. Vol. 20, No. 1 : 25-32.

[15] Liliasari. (2005). Membangun Keterampilan Berpikir Manusia Indonesia Melalui Pendidikan Sains. Pidato Pengukuhan Jabatan Guru Besar Dalam Ilmu Pendidikan IPA Pada Fakultas
PMIPA Universitas Pendidikan Indonesia. Bandung: tidak diterbitkan.

[16] Cheng, K., et. al. (2004). "Using Online Homeworks Systems Enhances Student. Learning of Physics Concept in an Introductory Physics Course". American Journal of Physics. 72 (11) 1447-1453.

[17] Nurmi.S \& Jaakola.T. (2007).Using Simulation, Laboratory Equipments and Conceptual Change Assignments to Enhance Learning of Simple Electricity.Published in Learning, Media, and Technology, 32 (1).

[18] Perkins. K, et.all. (2007). "PhET: Interactive Simulations for Teaching and Learning Physics". The Physics Teacher. (44). Pp. 18 - 23

[19] Finkelstein.N.D, et. All. (2005). Can Computer Simulations Replace Real Equipment in Undergraduate Laboratories?The Physics Teacher.Vol 76.Pp.1-8.

[20] Finkelstein.N.D. (2006).Using Online Resources In Teaching Introductory Pysics.American Journal of Physics.74. Pp. 949 - 953

\section{Biografi Penulis}

Gunawan, lahir di Gontar (Sumbawa) pada tanggal 1 Mei 1981. Penulis menyelesaikan pendidikan S1 pada Program Studi Pendidikan Fisika FKIP Unram pada tahun 2003. Pendidikan S2 dan S3 pada program studi Pendidikan Fisika di Universitas Pendidikan Indonesia. Sejak menyelesaikan program doktor pada Januari 2011, penulis aktif pada beberapa penelitian dan pengabdian kepada Masyarakat. Saat ini penulis bekerja sebagai Dosen Pendidikan Fisika, FKIP Unram. Fokus penelitian beberapa tahun terakhir pada pengembangan media pembelajaran berbasis ICT dan keterampilan berpikir tingkat tinggi. 